\title{
Comparative Investigation of the Antimicrobial Activity of PADMA 28 and Selected European Herbal Drugs
}

\author{
A. Weseler ${ }^{a} \quad$ R. Saller ${ }^{b} \quad$ J. Reichling ${ }^{a}$ \\ a Institute of Pharmacy and Molecular Biotechnology, University of Heidelberg \\ ${ }^{b}$ Department of Internal Medicine, Section of Complementary Medicine, Hospital of the University of Zurich
}

\section{Key Words}

Tibetan medicine - PADMA 28 - Quercus cortex · Hamamelidis folium - Menthae piperitae folium · Anserinae herba · Hyperici herba - Antibacterial and antifungal effect

\section{Summary}

Objective: PADMA 28 is a multicompound preparation of 20 herbs calcium sulphate, and camphor, derived from Tibetan medicine. It is usually used in the treatment of peripheral circulatory disorders, accompanied by the symptoms tingling, formication, heaviness and tenseness in arms and legs, numbness in hands and feet, and cramps in the calf. Recently, the question of whether appropriate preparations of PADMA 28 also exhibit antibacterial and antimy cotic activity has often been raised. As there are as yet no experi mental findings that answer this question, an in vitro study was carried out. In a parallel survey we investigated the antimicrobial prop erties of 5 herbal drugs which are commonly used in the traditional European folk medicine for the topical treatment of mild skin infections, wounds and eczematous skin lesions. Methods: The minimum inhibitory concentrations (MIC) and the minimum bactericida concentrations (MBC) of alcohol-based (tinctures) and aqueous (teas) herbal drug preparations were determined in vitro by a broth microdilution method for 5 Gram-positive and 5 Gram-negative bacteria, as well as the yeast Candida albicans. Results: The aqueous and alcohol-based PADMA 28 preparations as well as the corresponding preparations of the European herbal drugs showed an antibacterial effect against Gram-positive bacteria in vitro. These bacteria revealed a somewhat higher sensitivity to the teas prepared from the European herbal drugs (MIC: 1.3-20.0 mg/ml) than to the aqueous preparations of PADMA 28 (MIC: $5.0-40.0 \mathrm{mg} / \mathrm{ml}$ ). The better antibacterial activity of the European herbal drugs is probably based on their relatively high amount of tanning agents. On the other hand, all tested plant preparations inhibited not at all or only insufficiently the growth of the Gram-negative bacteria tested and that of Candida albicans. The ethanolic PADMA 28 tinctures showed an improved inhibitory effect on the Gram-positive bacteria (MIC $0.38-1.51 \%$ tincture or $0.38-1.51 \mathrm{mg}$ PADMA $28 / \mathrm{ml}$ ) compared with the aqueous preparations; this effect is comparable to the ethanolic tinctures of the tested European herbal drugs (MIC: $0.4-1.6 / 3.2 \%$ tincture or $0.4-1.6 / 3.2 \mathrm{mg}$ herbal drug/ml). Conclusion: All tested tea preparations and alcoholic tinctures of PADMA 28 as well as those of the selected European herbal drugs exhibited evident antibacterial effects against Gram-positive bacteria in vitro. On the other hand, except for Klebsiella pneumoniae, all Gram-negative bacteria tested and the yeast Candida albicans were insensitive against the different aqueous and alcohol-based plant extracts.

\author{
Schlüsselwörter \\ Tibetische Medizin . PADMA 28 - Quercus cortex · Hamamelis \\ folium · Menthae piperitae folium - Anserinae herba · Hyperici \\ herba - Antibakterielle und antimykotische Wirkung
}

\section{Zusammenfassung}

Hintergrund: PADMA 28 ist eine traditionelle tibetische Kräutermischung, die aus 20 verschiedenen Pflanzen, Kalziumsulfat und Kampfer besteht. Die Kräutermischung wird bevorzugt bei peripheren Durchblutungsstörungen angewendet, die mit Symptomen wie Kribbeln, Ameisenlaufen, Schweregefühl in den Armen und Beinen, Wadenkrämpfen sowie Einschlafen von Händen und Füssen einhergehen. In letzter Zeit stellte sich häufiger die Frage, ob PADMA 28 auch über antibakterielle und antimykotische Eigenschaften verfügt. Da bisher zu diesem Themenkreis keine experimentellen Daten vorliegen, sollte durch In-vitro-Untersuchungen diese Lücke geschlossen werden. Parallel dazu wurde die antimikrobielle Wirkung von 5 ausgewählten pflanzlichen Drogen untersucht, die in der traditionellen europäischen Volksmedizin zur äusserlichen Behandlung von leichten Hautinfektionen, Wunden und ekzematösen Hautläsionen eingesetzt werden. Methoden: Die antimikrobielle Wirkung von PADMA 28 und der ausgewählten europäischen pflanzlichen Drogen wurde in vitro mit Hilfe der Mikrodilutionsmethode bei jeweils 5 Gram-positiven und 5 Gram-negativen Bakterien sowie Candida albicans untersucht. Zur Testung wurden alkoholische (Tinkturen) und wässrige (Tees und Kaltmazerate) pflanzliche Drogenzubereitungen eingesetzt. Ergebnisse: Die wässrigen und alkoholischen Zubereitungen aus PADMA 28 und einer Auswahl europäischer pflanzlicher Drogen zeigten in vitro eine antibakterielle Wirkung gegenüber Gram-positiven Bakterien. Dabei zeigte sich, dass diese Bakterien gegenüber wässrigen Zubereitungen aus den europäischen pflanzlichen Drogen etwas empfindlicher reagierten (minimale Hemmkonzentration, MHK: 1,3-20,0 mg/ml) als vergleichsweise gegenüber wässrigen Zubereitungen aus PADMA 28 (MHK: 5,0-40,0 $\mathrm{mg} / \mathrm{ml}$ ). Die etwas bessere antimikrobielle Wirkung der wässrigen europäischen pflanzlichen Drogenzubereitungen basiert höchstwahrscheinlich auf deren relativ hohem Gehalt an gerbenden Inhaltsstoffen. Hingegen wurde das Wachstum der getesteten Gramnegativen Bakterien und von Candida albicans von allen Pflanzenzubereitungen nicht oder nur ungenügend gehemmt. Die ethanolischen PADMA -28-Tinkturen (MHK: 0,38-1,51\% Tinktur oder 0,38-1,51 mg PADMA 28/ml) zeigten im Vergleich zu den wässrigen Zubereitungen einen verbesserten inhibitorischen Effekt auf die Gram-positiven Bakterien und waren mit der antimikrobiellen Wirkung der getesteten europäischen Drogentinkturen (MHK: 0,4-1,6/3,2\% Tinktur oder 0,4-1,6/3,2 mg pflanzliche Droge/ml) vergleichbar. Die untersuchten Gram-negativen Bakterien hingegen zeigten gegenüber allen Tinkturen keine Sensitivität. Schlussfolgerung: Alle getesteten Teezubereitungen und alkoholischen Tinkturen von PADMA 28 sowie diejenigen der europäischen Arzneipflanzen zeigten in vitro deutliche antibakterielle Aktivität gegen Gram-positive Bakterien. Mit Ausnahme von Klebsiella pneumoniae konnte das Wachstum der Gram-negativen Bakterien und des Sprosspilzes Candida albicans mit den verschiedenen wässrigen und alkoholischen Pflanzenextrakten nicht beeinflusst werden.

\begin{tabular}{ll}
\hline KARGER & ( 2002 S. Karger GmbH, Freiburg \\
Fax +497614520714 & Accessible online at: \\
$\begin{array}{l}\text { E-mail Information@Karger.de } \\
\text { www.karger.com }\end{array}$ & www.karger.com/journals/fkm
\end{tabular}

Prof. Dr. Jürgen Reichling Institut für Pharmazie und Molekulare Biotechnologie, Universität Heidelberg Im Neuenheimer Feld 364 D-69120 Heidelberg (Germany) Tel. +49 622154 48-65, Fax -84 


\section{Introduction}

PADMA 28 is a special mixture of herbs that is used in traditional Tibetan medicine. It consists of dried plant material from 20 different plants, as well as calcium sulphate and camphor. In the past, the original composition has been modified numerous times to its present form. Today, PADMA 28 is manufactured in Switzerland and is commercially available as tablets. In Denmark, Poland and Switzerland PADMA 28 is registered as a remedy, in other countries like Austria, the Netherlands or the USA it is sold as a food supplement (in the USA under the name PADMA Basic). The indications are symptoms of peripheral circulatory disorders such as tingling, formication, a sensation of heaviness and tension in arms and legs, numbness of hands and feet, and intermittent claudication. Initial clinical studies could demonstrate that in patients suffering from these symptoms the maximum and pain-free walking distance was significantly increased after application of PADMA 28, as well as the vascular function (decrease of the ischemic window). Further applications in the field of other chronic inflammatory disorders are also described $[1,2]$. According to tradition, wound-healing properties were also attributed to the original 'Gabur' formula. A small ex vivo pilot study showed a positive influence of PADMA 28 on the spontaneous bactericidal activity against Escherichia coli and Salmonella typhimurium of blood serum in children suffering from recurrent respiratory tract infections [3]. In vitro tests revealed a strong antioxidant activity as well as antiproteolytic, immunomodulatory and antiinflammatory properties [4-6]. Recently, clinicians have been questioning more and more whether aqueous or alcohol-based preparations of the herbal mixture can be used for the topical treatment of mild skin infections, candidal mycosis, and vaginal infections e.g. in immunosuppressed patients. Until now in this field of study there are no experimental data available. Thus, it would be of great practical interest to evaluate the antimicrobial potential of PADMA 28 more closely. In the following survey we present the results of some preliminary screening studies in vitro. We determined the minimum inhibitory concentration (MIC) and the minimum bactericidal concentration (MBC) of hot and cold water infusions as well as of an alcohol-based preparation (tincture) of PADMA 28.

Furthermore, we compared these results with the antibacterial properties of selected single European herbs (St. John's wort, hamamelis, peppermint, silverweed and European oak) and their teas and tinctures respectively, which are used traditionally in complementary medicine as antimicrobial compounds and as potent external wound-healing agents for superficial skin injuries such as grazes and slight burns [7-11].

\section{Material and Methods}

Bacterial Strains

All the plant preparations were tested against 5 Gram-positive and 5 Gram-negative bacterial strains as well as against the yeast Candida albi- cans. Except for Listeria monocytogenes, all the other bacterial strains may be found on human skin. ATCC: American Type Culture Collection; NCTC: National Collection of Type Culture, UK.

Gram-positive bacteria:

Staphylococcus aureus

ATCC 6538

MRSA (methicillin-resistant Staphylococcus aureus)

Staphylococcus epidermidis

Streptococcus pyogenes

Listeria monocytogenes

Gram-negative bacteria:

Klebsiella pneumoniae

Escherichia coli

Pseudomonas aeruginosa

Acinetobacter baumanii (PADMA 28 only)

Serratia marcescens (PADMA 28 only)

Citrobacter freundii (European herbal drugs only)

Enterobacter aerogenes (European herbal drugs only)

Fungus:

Candida albicans

NCTC 10442

ATCC 15305

ATCC 12344

ATCC 9341

ATCC 10031

ATCC 11229

ATCC 15442

clinical isolate

clinical isolate

ATCC 8090

ATCC 13048

ATCC 10231

\section{Plant Material}

The PADMA 28 material was provided by PADMA AG, Schwerzenbach, Switzerland. We tested 2 different PADMA 28 compositions: 'PADMA 28 with camphor' was the original powdered plant mixture of the commercially available tablets, but without the excipients silicium dioxide and sorbitol; composition and dosage per tablet $(403.0 \mathrm{mg})$ : Aegle marmelos (Bengal quince) fruit (20.0 mg); Pimenta dioica (allspice) fruit (25.0 mg); Aquilegia vulgaris (columbine) aerial part $(15.0 \mathrm{mg})$; Calendula officinalis (marigold) flower (5.0 mg); Elletaria cardamomum (cardamon) fruit (30.0 $\mathrm{mg}$ ); Syzygium aromaticum (clove) flower bud (12.0 mg); Saussurea lappa (saussuria) root $(40.0 \mathrm{mg})$; Hedychium spicatum (ginger lily) rhizome (10.0 mg); Lactuca sativa (lettuce) leaf (6.0 mg); Cetraria islandica (Iceland moss) thallus (40.0 mg); Glycyrrhiza glabra (licorice) root (15.0 mg); Azedarachta indica (margosa) fruit $(35.0 \mathrm{mg})$; Terminalia chebula (myrobalan) fruit (30.0 mg); Plantago lanceolata (ribwort) aerial part (15.0 $\mathrm{mg})$; Polygonum aviculare (knotgrass) aerial part $(15.0 \mathrm{mg})$; Potentilla aurea (golden cinquefoil) aerial part (15.0 mg); Pterocarpus santalinus (red randalwood) wood (30.0 mg); Sida cordifolia (heart-leaved sida) aerial part $(10.0 \mathrm{mg})$; Valeriana officinalis (valerian) root $(10.0 \mathrm{mg})$; Aconitum napellus (monkshood) tuber $(1.0 \mathrm{mg})$; Calcii sulfas pulv. (gypsum; $20.0 \mathrm{mg}$ ); dextrocamphora (natural camphor; $4.0 \mathrm{mg}$ ). 'PADMA 28 without camphor' has the same composition, but without the camphor. The dried material of the 5 indigenous plants (Hyperici herba, Anserinae herba, Hamamelidis folium, Menthae piperitae folium, and Quercus cortex) was obtained from Caelo GmbH, Hilden, Germany.

\section{Preparation of the Test Solutions}

Tea

A volume of $100 \mathrm{ml}$ boiling water (aqua purificata) was poured onto $8.0 \mathrm{~g}$ of each of the PADMA 28 powders and onto $4.0 \mathrm{~g}$ of each of the single dried herbs, respectively. The aqueous PADMA 28 preparations were allowed to soak for $10 \mathrm{~min}$ and were then filtered. The filtrate was centrifuged for $20 \mathrm{~min}$ at $6000 \mathrm{rpm}$ to clarify the solution. Before testing, the supernatant was filtered under sterile conditions (pore $\varnothing: 0.22 \mu \mathrm{m}$ ).

The teas of the European plants were treated in the same way, except for the centrifugation step.

\section{Cold Maceration}

A volume of $100 \mathrm{ml}$ cold water was poured onto $8.0 \mathrm{~g}$ of each of the PADMA 28 powders. In accordance with the latest European Pharmacopoeia, the preparations were allowed to soak for $30 \mathrm{~min}$ with occasional shaking. After filtration the filtrate had to be centrifuged for $20 \mathrm{~min}$ at 
Table 1. Antimicrobial activity of aqueous tea preparations of Padma 28 against a selection of Gram-positive and Gram-negative bacteria as well as Candida albicans

\begin{tabular}{|c|c|c|c|c|c|c|c|c|}
\hline & \multicolumn{4}{|c|}{ Hot infusion (tea) } & \multicolumn{4}{|c|}{ Cold maceration } \\
\hline & \multicolumn{2}{|c|}{ Padma 28 with camphor } & \multicolumn{2}{|c|}{ Padma 28 without camphor } & \multicolumn{2}{|c|}{ Padma 28 with camphor } & \multicolumn{2}{|c|}{ Padma 28 without camphor } \\
\hline & $\mathrm{MIC}^{1}$ & $\mathrm{MBC}^{2}$ & MIC & $\mathrm{MBC}$ & MIC & $\mathrm{MBC}$ & MIC & $\mathrm{MBC}$ \\
\hline \multicolumn{9}{|l|}{ Gram-positive bacteria } \\
\hline Staphylococcus aureus & 5.0 & $10.0-20.0$ & 5.0 & $10.0-20.0$ & 5.0 & $10.0-20.0$ & 5.0 & $10.0-20.0$ \\
\hline$M R S A$ & 5.0 & $5.0-10.0$ & 5.0 & $5.0-10.0$ & 5.0 & $5.0-10.0$ & 5.0 & $5.0-10.0$ \\
\hline Staphylococcus epidermidis & 5.0 & $10.0-20.0$ & 5.0 & $10.0-20.0$ & 5.0 & $10.0-20.0$ & 5.0 & $10.0-20.0$ \\
\hline Streptococcus pyogenes & 20.0 & 40.0 & 20.0 & 40.0 & 20.0 & $>40.0$ & 20.0 & $>40.0$ \\
\hline Listeria monocytogenes & 40.0 & $>40.0$ & 40.0 & $>40.0$ & 40.0 & $>40.0$ & 40.0 & $>40.0$ \\
\hline \multicolumn{9}{|l|}{ Gram-negative bacteria } \\
\hline Klebsiella pneumoniae & $5.0-10.0$ & $5.0-10.0$ & $5.0-10.0$ & $5.0-10.0$ & $5.0-10.0$ & $5.0-10.0$ & $5.0-10.0$ & $5.0-10.0$ \\
\hline Escherichia coli & $>40.0$ & $>40.0$ & $>40.0$ & $>40.0$ & $>40.0$ & $>40.0$ & $>40.0$ & $>40.0$ \\
\hline Pseudomonas aeruginosa & $>40.0$ & $>40.0$ & $>40.0$ & $>40.0$ & $>40.0$ & $>40.0$ & $>40.0$ & $>40.0$ \\
\hline Acinetobacter baumanii & $>40.0$ & $>40.0$ & $>40.0$ & $>40.0$ & $>40.0$ & $>40.0$ & $>40.0$ & $>40.0$ \\
\hline Serratia marcescens & $>40.0$ & $>40.0$ & $>40.0$ & $>40.0$ & $>40.0$ & $>40.0$ & $>40.0$ & $>40.0$ \\
\hline \multicolumn{9}{|l|}{ Fungus } \\
\hline Candida albicans & $>40.0$ & $>40.0$ & $>40.0$ & $>40.0$ & $>40.0$ & $>40.0$ & $>40.0$ & $>40.0$ \\
\hline
\end{tabular}

${ }^{1} \mathrm{MIC}=$ Minimum inhibitory concentration (mg Padma 28/ml).

${ }^{2} \mathrm{MBC}=$ Minimum bactericidal concentration (mg Padma 28/ml).

$6000 \mathrm{rpm}$. Before the supernatant was added to the test system it was filtered under sterile conditions (pore $\varnothing: 0.22 \mu \mathrm{m}$ ).

\section{Tinctures}

The tinctures were prepared according to the latest edition of the European Pharmacopoeia. The PADMA 28 mixtures as well as each of the European dried herbs were mixed with ethanol $70 \%(\mathrm{~V} / \mathrm{V})$ in a 1 to 10 ratio (10 $\mathrm{g}$ herbal drug per $100 \mathrm{ml}$ ethanol) and allowed to stand for 5 days in the dark at room temperature with occasional shaking; then they were filtered.

\section{Camphor Test Solutions}

PADMA 28 contains camphor in a concentration of $4.0 \mathrm{mg}$ per tablet and $4.0 \mathrm{mg}$ in $403.0 \mathrm{mg}$ drug mixture, respectively. For the aqueous and ethanolic PADMA 28 preparations we used always $8.0 \mathrm{~g}$ and $10.0 \mathrm{~g}$ of the plant powder. Therefore, to investigate if the camphor proportion in PADMA 28 has any effect on the bacterial growth, test solutions of 80.0 $\mathrm{mg}$ camphor per $100 \mathrm{ml}$ water and $100.0 \mathrm{mg}$ camphor per $100 \mathrm{ml}$ ethanol $70 \%(\mathrm{~V} / \mathrm{V})$ were produced. Aliquots of both solutions were tested for their antimicrobial activity.

\section{Geometric Dilutions of Test Solutions}

For the geometric dilution of all test preparations physiological saline solution $(\mathrm{NaCl} 0.9 \%)$ was used. The aqueous preparations were tested in concentrations of $40.0 \mathrm{mg}, 20.0 \mathrm{mg}, 10.0 \mathrm{mg}, 5.0 \mathrm{mg}, 2.5 \mathrm{mg}, 1.25 \mathrm{mg}, 0.625 \mathrm{mg}$ and $0.3125 \mathrm{mg}$ PADMA $28 / \mathrm{ml}$, and $20.0 \mathrm{mg}, 10.0 \mathrm{mg}, 5.0 \mathrm{mg}, 2.5 \mathrm{mg}, 1.25$ $\mathrm{mg}, 0.625 \mathrm{mg}, 0.3125 \mathrm{mg}$ and $0.165 \mathrm{mg}$ herbal drug $/ \mathrm{ml}$, respectively. The alcohol-based tincture dilutions ranged from $50 \%(\mathrm{~V} / \mathrm{V})$ tincture to $0.05 \%$ $(\mathrm{V} / \mathrm{V})$ and were tested in parallel to a dilution of ethanol $70 \%(\mathrm{~V} / \mathrm{V})$.

\section{Test Protocols}

Test Method

The determination of MIC and MBC based on a modified broth microdilution method according to the DIN regulation 58940, Part 8 and Appendix 1, 1997, the official and obligatory German instruction for antibiotic sensitivity testing.

\section{Test Equipment}

The tests were performed in sterile 96-well microtitre plates (Greiner Labortechnik, Frickenhausen, Germany). $100 \mu \mathrm{l}$ test or control solution was pipetted into each well and mixed with every $100 \mu \mathrm{l}$ of the bacterial test inoculum. Each bacterium and each preparation was tested in duplicate and repeated twice. If there was a declination of the results, the test was repeated again.

\section{Culture Media}

Except for Streptococcus pyogenes, the bacteria tested were cultured in Iso-Sensitest Broth (Oxoid GmbH, Wesel, Germany). The streptococci were cultured in Brain Heart Infusion Broth (Merck, Darmstadt, Germany), and for the yeast Candida albicans Sabouraud Broth (BBL, USA) was used.

\section{Inoculum}

To obtain an appropriate exponential growth and a sufficient number of cells, the microorganisms were cultured overnight in an incubator at 37 ${ }^{\circ} \mathrm{C}$. After approx. $20 \mathrm{~h}$ the final inocula of the bacterial strains were adjusted to $5 \times 10^{5}$ colony-forming units (CFU) per $\mathrm{ml}$ and $5 \times 10^{3} \mathrm{CFU} / \mathrm{ml}$ for Candida albicans, respectively. The final number of bacteria of each inoculum was checked by the spiral plater counting method (Spiral Systems, USA).

\section{Incubation}

The inoculated microtitre plates were incubated at $37^{\circ} \mathrm{C}$ for $20 \pm 2 \mathrm{~h}$.

\section{Sterility and Growth Controls}

As sterility controls, aliquots of the growth and dilution media were incubated without bacteria in every test plate. Additionally, wells without a test substance, but only inoculum, were prepared to control the bacterial growth during the incubation period.

\section{Evaluation of Test Results}

After the incubation time, cell growth was visible as a precipitate or flocculation at the bottom of the wells. Both the MIC and the MBC were determined. The MIC is defined as the lowest concentration of the test sub- 
Table 2. Antimicrobial activity of aqueous tea preparations of 5 European herbal drugs against a selection of Gram-positive and Gram-negative bacteria as well as Candida albicans

\begin{tabular}{|c|c|c|c|c|c|c|c|c|c|c|}
\hline & \multicolumn{2}{|c|}{ Quercus cortex } & \multicolumn{2}{|c|}{ Hamamelidis folium } & \multicolumn{2}{|c|}{ Menthae piperitae folium } & \multicolumn{2}{|c|}{ Anserinae herba } & \multicolumn{2}{|c|}{ Hyperici herba } \\
\hline & $\mathrm{MIC}^{1}$ & $\mathrm{MBC}^{2}$ & MIC & $\mathrm{MBC}$ & MIC & $\mathrm{MBC}$ & MIC & $\mathrm{MBC}$ & $\mathrm{MIC}$ & $\mathrm{MBC}$ \\
\hline \multicolumn{11}{|l|}{ Gram-positive bacteria } \\
\hline Staphylococcus aureus & $2.5-5.0$ & $2.5-5.0$ & 2.5 & 2.5 & 5.0 & 5.0 & 5.0 & 5.0 & 2.5 & 2.5 \\
\hline$M R S A$ & 2.5 & 2.5 & 1.3 & 2.5 & $1.3-2.5$ & $1.3-2.5$ & 2.5 & 2.5 & 2.5 & 2.5 \\
\hline Staphylococcus epidermidis & 1.3 & $2.5-5.0$ & 1.3 & 2.5 & 2.5 & 2.5 & 2.5 & 5.0 & 2.5 & 5.0 \\
\hline Streptococcus pyogenes & 10.0 & $10.0-20.0$ & 10.0 & 20.0 & 20.0 & $>20.0$ & 20.0 & $>20.0$ & $10.0->10.0$ & $>10.0$ \\
\hline Listeria monocytogenes & 5.0 & $5.0-10.0$ & 2.5 & 5.0 & $2.5-5.0$ & 5.0 & 5.0 & $5.0-10.0$ & 2.5 & 5.0 \\
\hline \multicolumn{11}{|l|}{ Gram-negative bacteria } \\
\hline Klebsiella pneumoniae & $2.5-5.0$ & $5.0-10.0$ & 5.0 & $5.0-10.0$ & 5.0 & 5.0 & $2.5-5.0$ & $2.5-5.0$ & $10.0-20.0$ & $10.0-20.0$ \\
\hline Escherichia coli & $>20.0$ & $>20.0$ & $>20.0$ & $>20.0$ & $>20.0$ & $>20.0$ & $>20.0$ & $>20.0$ & $>20.0$ & $>20.0$ \\
\hline Pseudomonas aeruginosa & $>20.0$ & $>20.0$ & $>20.0$ & $>20.0$ & $>20.0$ & $>20.0$ & $>20.0$ & $>20.0$ & $>20.0$ & $>20.0$ \\
\hline Citrobacter freundii & 20.0 & 20.0 & $>20.0$ & $>20.0$ & $>20.0$ & $>20.0$ & $>20.0$ & $>20.0$ & $>20.0$ & $>20.0$ \\
\hline Enterobacter aerogenes & $>20.0$ & $>20.0$ & $>20.0$ & $>20.0$ & $>20.0$ & $>20.0$ & $>20.0$ & $>20.0$ & $>20.0$ & $>20.0$ \\
\hline \multicolumn{11}{|l|}{ Fungus } \\
\hline Candida albicans & $>20.0$ & $>20.0$ & $>20.0$ & $>20.0$ & $>20.0$ & $>20.0$ & $>20.0$ & $>20.0$ & $>20.0$ & $>20.0$ \\
\hline
\end{tabular}

stance at which the microorganisms tested do not show any visible growth. The MBC is defined as the lowest concentration of the test substance at which $99.9 \%$ of the microorganisms have been killed. For its determination a sample of $10 \mu \mathrm{l}$ broth was removed from each well, dropped onto a blood-agar plate for bacteria or an SPS-agar plate (Sabouraud agar supplemented with penicillin and streptomycin; Merck) for Candida albicans and incubated for further $24 \mathrm{~h}$ at $37^{\circ} \mathrm{C}$. After that incubation period the lowest concentration without any colony growth on the agar plate was defined as the MBC.

\section{Results}

Tea Preparations and Cold Maceration of PADMA 28

The efficacy range and intensity of the bacterial growth inhibition was the same for both aqueous preparations, the hot infusion and the cold maceration (table 1).

At a concentration of $5.0 \mathrm{mg}$ PADMA $28 / \mathrm{ml}$ the growth of the staphylococcal bacteria was inhibited. To inhibit bacterial growth of Streptococcus pyogenes, a concentration of 20.0 $\mathrm{mg} / \mathrm{ml}$ was required, for Listeria monocytogenes even 40.0 $\mathrm{mg} / \mathrm{ml}$. The MBC was found to be one or two concentration steps higher than the MIC. In contrast to this, the growth of the Gram-negative bacteria and of Candida albicans was not affected even at concentrations of $40.0 \mathrm{mg} / \mathrm{ml}$. Klebsiella pneumoniae, a rod-shaped Gram-negative bacterium of the family Enterobacteriaceae, was the only germ that reacted sensitively to both the tea preparation and the cold maceration of 10.0 mg PADMA 28/ml.

Since the antibacterial potential of both aqueous preparations was identical, the quality and quantity of the plant compounds responsible for the effect seem to be independent of whether the extract is prepared with hot water and a short extraction time or with cold water but a threefold longer extraction time.
Furthermore, no significant differences in efficacy were observed between the traditional PADMA 28 mixture with camphor and the drug mixture without camphor. In addition, the individually prepared aqueous camphor preparations did not show any effect on either the bacterial or the yeast growth.

\section{Tea Preparations of Selected European Drugs}

In a parallel study we tested the antimicrobial potential of tea preparations of Quercus cortex, Hamamelidis folium, Menthae piperitae folium, Anserinae herba und Hyperici herba (table 2). Like the PADMA 28 preparations, these teas made from single herbal drugs inhibited the growth of Gram-positive bacteria whereas, except for Klebsiella pneumoniae, the Gram-negative microorganisms as well as the Candida strain remained unaffected.

Interestingly, the MIC and MBC values of the hot single European herbal drug infusions were one to two dilution steps lower compared with the preparations of the Tibetan remedy. With respect to the aqueous preparation of PADMA 28 the Gram-positive bacterium Listeria monocytogenes exhibited an evidently higher sensitivity (about 8-fold) against the tea preparations of the European herbal drugs (MIC: 2.5-5.0 mg herbal drug/ml) (tables 1,2). The somewhat better antimicrobial potency of the European herbal drugs compared with PADMA 28 may probably be explained by the fact that these European plants typically contain tanning agents. Low-molecular-weight tanning agents are water soluble and well known for their antibacterial effect.

\section{PADMA 28 Tinctures}

The efficacy of the alcohol-based PADMA 28 preparations (tinctures) can only be evaluated in direct comparison with an 
Table 3. Antimicrobial activity of alcoholic tinctures of Padma $28^{1}$ against a selection of Grampositive and Gramnegative bacteria as well as Candida albicans

\begin{tabular}{|c|c|c|c|c|c|c|}
\hline & \multicolumn{2}{|c|}{ Padma 28 with camphor } & \multicolumn{2}{|c|}{ Padma 28 without camphor } & \multicolumn{2}{|c|}{$\begin{array}{l}\text { Ethanol } 70 \%(\mathrm{~V} / \mathrm{V}) \\
\text { (alcohol control) }\end{array}$} \\
\hline & $\mathrm{MIC}^{2}$ & $\mathrm{MBC}^{3}$ & $\mathrm{MIC}$ & $\mathrm{MBC}$ & $\mathrm{MIC}$ & $\mathrm{MBC}$ \\
\hline \multicolumn{7}{|l|}{ Gram-positive bacteria } \\
\hline Staphylococcus aureus & $0.38-0.76$ & $1.51-3.13$ & $0.38-0.76$ & $1.51-3.13$ & 12.5 & 25.0 \\
\hline$M R S A$ & 1.51 & $1.51-3.13$ & 1.51 & $1.51-3.13$ & 12.5 & 25.0 \\
\hline Staphylococcus epidermidis & $0.38-0.76$ & 3.13 & $0.38-0.76$ & 3.13 & 6.3 & 25.0 \\
\hline Streptococcus pyogenes & $0.38-0.76$ & 0.76 & $0.38-0.76$ & 0.76 & 6.3 & 6.3 \\
\hline Listeria monocytogenes & 1.51 & 3.13 & 1.51 & 3.13 & 3.2 & 12.5 \\
\hline \multicolumn{7}{|l|}{ Gram-negative bacteria } \\
\hline Klebsiella pneumoniae & $3.13-6.25$ & $3.13-6.25$ & $3.13-6.25$ & $3.13-6.25$ & 6.3 & 6.3 \\
\hline Escherichia coli & 6.25 & $6.25-12.5$ & 6.25 & $6.25-12.5$ & 6.3 & 12.5 \\
\hline Pseudomonas aeruginosa & $3.13-6.25$ & 6.25 & $3.13-6.25$ & 6.25 & 3.2 & 12.5 \\
\hline Acinetobacter baumanii & $3.13-6.25$ & $3.13-6.25$ & $3.13-6.25$ & $3.13-6.25$ & 6.3 & 12.5 \\
\hline Serratia marcescens & 6.25 & 6.25 & 6.25 & 6.25 & 6.3 & 6.3 \\
\hline \multicolumn{7}{|l|}{ Fungus } \\
\hline Candida albicans & 12.5 & 12.5 & 12.5 & 12.5 & 25.0 & 25.0 \\
\hline
\end{tabular}

${ }^{1}$ Tincture 1:10; 1 vol. $\%$ ethanolic tincture = $1 \mathrm{mg}$ herbal drug $/ \mathrm{ml}$.

${ }^{2} \mathrm{MIC}=$ Minimum inhibitory concentration $(\%$ tincture, $\mathrm{V} / \mathrm{V})$.

${ }^{3} \mathrm{MBC}=$ Minimum bactericidal concentration $(\%$ tincture, $\mathrm{V} / \mathrm{V})$. alcohol-based control solution of the same ethanol concentration, i.e. $70 \%(\mathrm{~V} / \mathrm{V})$, which was used to prepare the tinctures. Regarding the efficacy of the tinctures against the Gram-negative bacteria and the yeast the results of the ethanol control (MIC: $6.3-25.0 \%(\mathrm{~V} / \mathrm{V})$ ethanol) clearly show that the antibacterial activity is solely a result of the alcohol.

In contrast, the effect of the PADMA 28 tinctures on the staphylococci (MIC: $0.38-1.51 \%$ tincture or $0.38-1.51 \mathrm{mg}$ Padma 28/ml), Streptococcus pyogenes (MIC: 0.38-0.76\% tincture or $0.38-0.76 \mathrm{mg}$ Padma $28 / \mathrm{ml}$ ), and Listeria monocytogenes (MIC: $1.51 \%$ tincture or $1.51 \mathrm{mg}$ Padma $28 / \mathrm{ml}$ ) was remarkable (table 3). With regard to $\mathrm{mg}$ Padma $28 / \mathrm{ml}$ broth it was plain to see that less than a tenth of the amount of the herbal mixture was effective, compared to the aqueous Padma 28 preparation (tables 1,3 ). This means that the plant compounds that are responsible for the antibacterial activity show more lipophilic properties and can be enriched to a far higher concentration in an ethanol preparation than might be possible after an aqueous extraction procedure.

The presence of camphor in the Tibetan herb mixture did not affect the antimicrobial activity of PADMA 28 tinctures at all.

\section{Tinctures from Selected European Herbal Drugs}

The tinctures of the single European herbal drugs show similar results compared with the Tibetan remedy. The growth of the Gram-negative bacteria and Candida albicans was not more strongly inhibited by the alcohol-based plant preparations than by ethanol itself (table 4). On the other hand, the Gram-positive bacteria proved to be very sensitive to the tinctures. In comparison with the PADMA 28 results, the MIC and $\mathrm{MBC}$ values of the ethanolic tinctures of the selected European herbal drugs were more or less within the same range of antibacterial activity (MIC: $0.4-1.6 / 3.2 \%$ tincture or 0.4-1.6/3.2 mg herbal drug/ml).

\section{Discussion}

The present study offers some interesting aspects about the antibacterial activity of some aqueous and ethanolic plant preparations in vitro: on the one hand PADMA 28, a complex powdered herb mixture, and on the other hand 5 single European herbal drugs used moreover in complementary medicine for the topical treatment of mild skin infections and eczematous skin lesions. On the basis of the amount of tanning agents the European herbal drugs are known as antimicrobial agents. Therefore, the comparative investigation of the antimicrobial activity of PADMA 28 and selected European herbal drugs should help to value and classify the antimicrobial effectiveness of the Tibetan remedy.

Irrespective of the preparation procedure, all the plant preparations tested showed clear antibacterial effects against Grampositive bacteria. The growth of the Gram-negative bacteria and the yeast Candida albicans was not inhibited, with the exception of Klebsiella pneumoniae. In principle the antimicrobial activity of PADMA 28 teas and tincture was comparable with the corresponding preparations of the selected European herbal drugs except for Listeria monocytogenes. This Grampositive bacterium was much more sensitive against the tea preparations of the European herbal drugs (MIC: 2.5-5.0 $\mathrm{mg} / \mathrm{ml}$ ) than against the aqueous preparations of PADMA 28 (MIC: $40.0 \mathrm{mg} / \mathrm{ml}$ ).

Extracting the multicompound mixture PADMA 28 with ethanol (70 vol.\%), the tincture showed a remarkable in- 
Table 4. Antibacterial activity of ethanolic tinctures of 5 European herbal drugs against a selection of Gram-positive and Gram-negative bacteria as well as Candida albicans

\begin{tabular}{|c|c|c|c|c|c|c|c|c|c|c|c|c|}
\hline & \multicolumn{2}{|c|}{ Quercus cortex } & \multicolumn{2}{|c|}{$\begin{array}{l}\text { Hamamelidis } \\
\text { folium }\end{array}$} & \multicolumn{2}{|c|}{$\begin{array}{l}\text { Menthae piperitae } \\
\text { folium }\end{array}$} & \multicolumn{2}{|l|}{$\begin{array}{l}\text { Anserinae } \\
\text { herba }\end{array}$} & \multicolumn{2}{|l|}{$\begin{array}{l}\text { Hyperici } \\
\text { herba }\end{array}$} & \multicolumn{2}{|c|}{$\begin{array}{l}\text { Ethanol } 70 \%(\mathrm{~V} / \mathrm{V}) \\
\text { (alcohol control) }\end{array}$} \\
\hline & $\mathrm{MIC}^{1}$ & $\mathrm{MBC}^{2}$ & MIC & $\mathrm{MBC}$ & MIC & $\mathrm{MBC}$ & MIC & $\mathrm{MBC}$ & MIC & $\mathrm{MBC}$ & MIC & $\mathrm{MBC}$ \\
\hline \multicolumn{13}{|l|}{ Gram-positive bacteria } \\
\hline Staphylococcus aureus & 1.6 & 1.6 & 0.4 & 0.8 & 1.6 & 1.6 & 1.6 & $0.8-1.6$ & 1.6 & 1.6 & 12.5 & 25.0 \\
\hline$M R S A$ & 1.6 & 1.6 & 0.4 & 0.8 & 0.8 & $0.8-1.6$ & 1.6 & $1.6-3.2$ & $0.8-1.6$ & 3.2 & 12.5 & 25.0 \\
\hline Staphylococcus epidermidis & 0.8 & 3.2 & 0.4 & $0.8-1.6$ & 1.6 & 1.6 & $0.8-1.6$ & 3.2 & 1.6 & 6.3 & 6.3 & 25.0 \\
\hline Streptococcus pyogenes & $1.6-3.2$ & 3.2 & 0.8 & $0.8-1.6$ & 0.8 & 0.8 & $0.8-1.6$ & $0.8-1.6$ & 1.6 & 1.6 & 6.3 & 6.3 \\
\hline Listeria monocytogenes & 1.6 & 3.2 & 0.8 & $0.8-1.6$ & 0.8 & $0.8-1.6$ & 0.8 & 0.8 & 0.8 & 1.6 & 3.2 & 12.5 \\
\hline \multicolumn{13}{|l|}{ Gram-negative bacteria } \\
\hline Klebsiella pneumoniae & 1.6 & 3.2 & 1.6 & 3.2 & 0.8 & 0.8 & 1.6 & 1.6 & 1.6 & 3.2 & 6.3 & 6.3 \\
\hline Escherichia coli & 6.3 & 12.5 & 6.3 & 6.3 & 6.3 & $6.3-12.5$ & 6.3 & 12.5 & 6.3 & 12.5 & 6.3 & 12.5 \\
\hline Pseudomonas aeruginosa & 3.2 & 6.3 & 3.2 & 6.3 & 3.2 & $6.3-12.5$ & 3.2 & 6.3 & 3.2 & 6.3 & 3.2 & 12.5 \\
\hline Citrobacter freundii & 6.3 & 6.3 & 6.3 & 6.3 & 6.3 & 6.3 & 6.3 & 6.3 & 6.3 & 6.3 & 6.3 & 12.5 \\
\hline Enterobacter aerogenes & 6.3 & 12.5 & 6.3 & 12.5 & 6.3 & 6.3 & 6.3 & 12.5 & 6.3 & 12.5 & 6.3 & 12.5 \\
\hline \multicolumn{13}{|l|}{ Fungus } \\
\hline Candida albicans & 12.5 & 12.5 & 12.5 & 12.5 & 12.5 & 12.5 & 12.5 & 12.5 & 12.5 & 12.5 & 25.0 & 25.0 \\
\hline
\end{tabular}

1 vol. $\%$ ethanolic tincture $=1 \mathrm{mg}$ herbal drug $/ \mathrm{ml}$.

${ }^{1} \mathrm{MIC}=$ Minimum inhibitory concentration $(\%, \mathrm{~V} / \mathrm{V})$.

${ }^{2} \mathrm{MBC}=$ Minimum bactericidal concentration $(\%, \mathrm{~V} / \mathrm{V})$.

hibitory effect on the Gram-positive bacteria (MIC: 0.35-1.39 $\mathrm{mg} / \mathrm{ml}$ ), which was 6-25 times lower than that of the aqueous extracts. Both PADMA 28 mixtures, with and without camphor, showed identical growth inhibitory effects, and even for the alcoholic tincture no inhibiting influence of the camphor amount could be observed.

For a simple tea preparation of PADMA 28 the water temperature and the time of extraction had no influence on its antibacterial activity. But with regard to a practical use a hot water preparation should always be preferred because of a lower microbial contamination.

As there are many different staphylococci strains that form a main part of the normal skin flora, these may become pathogenic after a skin injury. Therefore it seems to be promising to tentatively test, in vivo, the aqueous and ethanolic preparations of PADMA 28 for the topical treatment of mild skin infections, for example at the fingers, toes or soles of the feet.

\section{References}

1 Saller R, Kristof O, Reichling J: PADMA 28 - Ein traditionelles und modernes Phytotherapeutikum. Z Phytother 1997;18:323-331.

2 Sallon S, Beer G, Rosenfeld J, Anner H, Volcoff D, Ginsberg G, Paltiel O, Berlatzky Y: The efficacy of PADMA 28, a herbal preparation, in the treatment of intermittent claudication: A controlled doubleblind pilot study with objective assessment of chronic occlusive arterial disease patients. J Vasc Invest 1998;4:129-136.

3 Jankowski S, Jankowski A, Zielinska S, Walczuk M: Influence of PADMA 28 on the spontaneous bactericidal activity of blood serum in children suffering from recurrent infections of the respiratory tract. Phytother Res 1991;5:120-123.

4 Ginsburg I, Sadovnik M, Sallon S: PADMA 28, a traditional Tibetan herbal preparation inhibits the respiratory burst in human neutrophils, the killing of epithelial cells by mixtures of oxidants and proinflammatory agonists and peroxidation of lipids. Inflammopharmacology 1999;7:47-62.

5 Suter M, Richter C: Anti- and pro-oxidative properties of PADMA 28, a Tibetan herbal formulation. Redox Rep 2000;5:17-22.

6 Moeslinger T, Friedl R, Volf I, Brunner M, Koller E, Spieckermann PG: Inhibition of inducible nitric oxide synthesis by the herbal preparation PADMA 28 in macrophage cell line. Can J Physiol Pharmacol 2000;78:861-866.

7 Korting HC, Schäfer-Korting M, Hart H, Laux P, Schmid M: Antiinflammatory activity of hamamelis distillate applied topically to the skin - influence of vehicle and dose. Eur J Clin Pharmacol 1993;44: $315-318$.
8 Stahl-Biskup E: Mentha; in Hänsel R, Keller K, Rimpler H, Schneider G (Hrsg): Hagers Handbuch der Pharmazeutischen Praxis. Heidelberg, Springer, 1993, Bd 5, pp 821-848.

9 Moeck S: Quercus; in Hänsel R, Keller K, Rimpler H, Schneider G (Hrsg): Hagers Handbuch der Pharmazeutischen Praxis. Heidelberg, Springer, 1994, Bd 6, pp 335-354.

10 Reichling J, Weseler A, Saller R: A current review of the antimicrobial activity of Hypericum perforatum L. Pharmacopsychiatry 2001;34(suppl 1):116118.

11 Gloor M, Reichling J, Wasik B, Holzgang HE: Antiseptic effect of a topical dermatological formulation that contains Hamamelis distillate and urea. Forsch Komplementärmed Klass Naturheilkd 2002;9:153-159. 